We thank the physicians at the Leopold II Clinic and the medical centre of the Ministry of Foreign Affairs for their cooperation, and G Vercauteren and V Hanquart for the laboratory testing. The screening programme was funded by the General Administration of Cooperation Development, and the study was supported by the Ministry of Health in Brussels.

1 Instituut voor Hygiène en Epidemiologie. AIDS in België. 3I Maart 1988. Brussels: Ministry of Health, 1988.

2 Curran JW, Jaffe HW, Hardy AM, Morgan WM, Selik RM, Dondero TJ. Epidemiology of HIV infection and AIDS in the United States. Science 1988;239:610-6.

3 World Health Organisation Collaborating Centre on AIDS, Paris. AIDSsurveillance in Europe: situation by 31 December 1987. Paris: WHO, 1988. (Report No 10.)

4 Quinn TC, Mann JM, Curran JW, Piot P. AIDS in Africa: an epidemiologic paradigm. Science 1986;234:955-63.

5 Piot P Plummer FA, Mhalu FS, Chin J, Lamboray JL, Mann JM. AIDS: an international perspective. Science 1988;239:573-9.
in

6 Vercauteren G, Piot P, van der Groen G. Comparison of enzyme immunoassays and an immunofluorescence test for detection of antibody to human immunodeficiency virus in African sera. European fournal of Microbiologv 1987;6:132-5

7 Kleinbaum DG, Kupper LL, Morgenstern H. Epidemiologic research; prin- ciples and quantitative methods. London: Lifetime Learning Publications (Wadworth), 1982

8 Breslow NE, Day NE. Statistical methods in cancer research. Vol I. The analysis of case-control studies. Lyons: International Agency for Research on Cancer, of case-control studies. Lyons: Internation

9 Tauris P, Black FT. Heterosexuals importing HIV from Africa. Lancet 1987; i:325.

10 Piot P, Plummer FA. Rey MA, et al. Retrospective seroepidemiology of AIDS virus infection in Nairobi populations. I Infect Dis 1987;155:1108-12.

11 Van de Perre P, Clumeck N, Carael $M$, et al. Female prostitutes: a risk group for infection with the human T cell lymphotropic virus type III. Lancel 1985;ii:524-6.

12 Vittecoq D, Roue RT, Mayaud C, et al. Acquired immunodeficiency syndrome after travelling in Africa: an epidemiological study in seventeen Caucasian patients. Lancet 1987; i:612-4.

13 Centers for Disease Control. Heterosexual transmission of HTLV III/LAV. $M M W R$ 1985;34:2051-2.

14 Mann JM, Francis H, Davachi F, et al. Risk factors for human immunodeficiency virus seropositivity among children 1-24 months old in Kinshasa, Zaire. Lancet 1986;ii:654-6.

15 Lepage P, van de Perre P, Caraël M, Butzler JP. Are medical injections a risk factor for HIV infection in children? Lancet 1986;ii: 1103-4.

16 Mann JM, Francis H, Quinn TC, et al. Surveillance among household members of confirmed AIDS-cases and controls in Kinshasa, Zaire. JAMA 1986;256:721-4

17 Friedland GH, Saltzman BR, Roger MF, et al. Lack of transmission of HTLVIII/LAV infection to household contacts of patients with AIDS or AIDSrelated complex with oral candidiasis. $N$ Engl f Med 1986;314:344-9.

(Accepted 16 fune 1988)

\title{
A prospective study of maternal and fetal outcome in acute Lassa fever infection during pregnancy
}

\author{
Michael E Price, Susan P Fisher-Hoch, Robert B Craven, Joseph B McCormick
}

\begin{abstract}
Several viral infections have been reported to result in more severe disease in pregnant than non-pregnant women, but the relative risks have not been well characterised. This has now been done for Lassa fever in a prospective study of 68 pregnant and 79 non-pregnant women who were admitted to hospital in Sierra Leone with confirmed Lassa fever. Lassa fever was the main cause of maternal mortality in the hospital, accounting for $25 \%$ of maternal deaths. Twelve of $\mathbf{4 0}$ patients in the third trimester died, compared with two of 28 in the first two trimesters and 10 of 79 non-pregnant women. The odds ratio for death in the third trimester compared with the first two trimesters was 5.57 (95\% confidence intervals 1.02 to 30.26$)$. The condition of the mother improved rapidly after evacuation of the uterus, whether by spontaneous abortion, evacuation of retained products of conception, or normal delivery; 10 of 26 women without uterine evacuation died, but only four of 39 women with evacuation died $(p=0.0016)$. The odds ratio for death with pregnancy intact was 5.47 (95\% confidence interval 1.35 to $22 \cdot 16$ ). Fetal and neonatal loss was $87 \%$.
\end{abstract}

The risk of death from Lassa fever in the third trimester is significantly higher than that in the first two trimesters and higher than that for non-pregnant women, but evacuation of the uterus can significantly improve the mother's chance of survival.

Nixon Memorial Hospital, Segbwema, Sierra Leone Michael E Price, MRCP

Centres for Disease Control Center for Infectious Diseases, Division of Viral Diseases, Special Pathogens Branch, Atlanta, GA 30333 , United States

Susan P Fisher-Hoch, MD Joseph B McCormick, MD Robert B Craven, MD

Correspondence to: Dr FisherHoch. age who had been admitted to hospital with Lassa fever.

Lassa fever is endemic in eastern Sierra Leone, where it is an important cause of admission to hospital and death. ${ }^{3}$ We have isolated the Lassa fever virus from fetal organs after spontaneous abortion and have obtained the highest titres of virus from human placenta ${ }^{3-5}$ In two early investigations, which reported eight maternal deaths due to Lassa fever, ascertainment of cases was uncertain and data were poorly substantiated ${ }^{67}$ To provide accurate data on the risk of death and complications of Lassa fever in pregnancy. we studied 68 pregnant patients with Lassa fever during the four years $1981-5 .{ }^{589}$ We studied pregnant women requiring admission to hospital and did not include febrile pregnant women treated in antenatal clinics and not admitted to hospital.

\section{Patients and methods}

Febrile women with complications of pregnancy admitted to the Nixon Memorial Hospital, Segbwema, either from an antenatal clinic or through the medical outpatient clinic were routinely investigated for clinical and laboratory evidence of Lassa fever. Lassa fever was confirmed by finding on immunofluorescence a fourfold rise in the titre of IgG to Lassa fever virus (minimum final titre of 16) or an IgG titre of $\geqslant 256$ with IgM antibody to Lassa fever, or by isolating the virus. The duration of gestation was estimated from the height of the uterine fundus because patients could rarely give accurate dates of their last menstrual period. The controls in this study were the women of childbearing age who were admitted to hospital with confirmed Lassa fever and in whom pregnancy was excluded.

Haemoglobin concentration, white cell and platelet counts and serum aspartate transaminase activity were measured and urine analysed for all patients on admission and during the course of the illness at the hospital laboratories and the Sierra Leone Ministry of Health and Centers for Disease Control Lassa fever research project laboratory at the hospital. Facilities for bacteri- 
ology were not available. Virus was isolated at the Centers for Disease Control, Atlanta, from specimens of serum preserved in liquid nitrogen and transported on dry ice. Serological testing was carried out at the hospital and confirmed in Atlanta.

Women less than 20 weeks pregnant suspected of having Lassa fever were admitted to hospital and treated on the general female ward. If the clinical diagnosis was strongly suspected or had been confirmed by serologic testing, the patient was transferred to an isolation room. Women more than 20 weeks pregnant were admitted to the maternity ward and barrier nursed; they were transferred to the maternity isolation room when Lassa fever was confirmed, and their infants were delivered there. Whenever possible these patients were attended by midwives known to have antibodies to Lassa virus.

The nurses used disposable gloves and masks and reusable gowns. Masks and gloves were discarded into $10 \%$ sodium hypochlorite (obtained locally as fresh bleach) prepared daily and available outside each isolation room or at the foot of the bed of each patient being barrier nursed on the main wards. Sodium hypochlorite was also applied to spills and used to soak linen and other discarded items.

All patients were treated with chloroquine and broad spectrum antibiotics until Lassa fever was confirmed. When indicated oxytocin infusion was used to induce labour. When evacuation of retained products of conception was required it was performed in the operating theatre under thiopentone or ketamine anaesthesia, after which ergometrine was given. Caesarean section was performed, when needed, in the operating theatre under ketamine anaesthesia by one of us (MEP). Standard operating techniques were used, and special care was taken to avoid injuries from needles. All theatre staff wore two pairs of gloves (this is important in hospitals where, for economy, operating gloves are resterilised and reused). Instruments were decontaminated in $10 \%$ fresh sodium hypochlorite solution for 30 minutes. Soiled gowns and drapes were soaked in bleach overnight, and the theatre floor was mopped with bleach.

Patients who recovered before term and were discharged were later visited in their villages to ascertain the outcome of the pregnancy. Seven pregnant patients were lost to follow up and five women were still pregnant when the study ended.

\section{Results}

During the four years of this study we diagnosed Lassa fever in 233 women admitted to the study hospital, 68 of whom were pregnant; the number of pregnant patients seen increased by weeks of gestation (table I). Fourteen patients died of the disease, giving a case fatality rate of $21 \%$, slightly higher than the $16-18 \%$

TABLE I-Mortality in Lassa fever during pregnancy and in controls

\begin{tabular}{|c|c|c|c|}
\hline & No of cases & No of deaths & $\begin{array}{l}\text { Case fatality } \\
\text { rate }(\%)\end{array}$ \\
\hline All pregnant women & 68 & 14 & 21 \\
\hline First trimester & 6 & 1 & 18 \\
\hline $9-11$ Weeks & 2 & 1 & \\
\hline 12-15 Weeks & 4 & & \\
\hline Second trimester & 22 & 1 & 5 \\
\hline 16-19 Weeks & 7 & 1 & \\
\hline $21-23$ Weeks & 6 & & \\
\hline 24-27 Weeks & 9 & & \\
\hline Third trimester & 40 & 12 & $30^{\star}$ \\
\hline 28-31 Weeks & 12 & 2 & \\
\hline 32-35 Weeks & 13 & 4 & \\
\hline$\geqslant 36$ Weekst & 15 & 6 & \\
\hline Non-pregnant women & 79 & 10 & 13 \\
\hline
\end{tabular}

${ }^{\star} \mathrm{p}=0.05\left(\chi^{2}=3.95, \mathrm{df}=1\right) ;$ odds ratio $5.57(95 \%$ confidence interval 1.01 to $30 \cdot 26)$

IIncludes six women with puerperal infection after delivery at home up to one week before admission to hospital. previously reported for patients in hospital with Lassa fever ${ }^{89}$ The case fatality rate was significantly higher in the third trimester $(30 \%, 12 / 40)$ than in the first two trimesters $(7 \%, 2 / 28)\left(\chi^{2}=3.95, \mathrm{df}=1, \mathrm{p}=0.05\right)$, giving an odds ratio of 5.57 ( $95 \%$ confidence interval 1.02 to $30 \cdot 26$ ). Lassa fever was the main single cause of death in the maternity ward during the study period, accounting for $25 \%$ of the 56 maternal deaths in 2639 deliveries. The case fatality rate in the non-pregnant women with Lassa fever $(13 \%, 10 / 79)$ was not significantly different from that in all the pregnant women but was significantly different from that in women in the third trimester $\left(\chi^{2}=4.21, \mathrm{df}=1, \mathrm{p}=0.04\right.$; odds ratio $2 \cdot 96,95 \%$ confidence interval $1 \cdot 04$ to $8 \cdot 46$ ).

Increased aspartate transaminase activity and a higher concentration of virus on admission were significantly correlated with outcome, as previously observed, ${ }^{89}$ especially in the last trimester, when the mean aspartate transaminase activity in the 27 surviving patients was $261 \mathrm{IU} / \mathrm{l}$ (median 75 ) compared with $3154 \mathrm{IU} / 1$ (median 2435) in the 12 patients who died. The case fatality rate in 31 patients with an aspartate transaminase activity of $<150 \mathrm{IU} / 1$ on admission was $7 \%$ (two deaths), compared with $34 \%$ (12 deaths) in 35 patients with an activity $\geqslant 150 \mathrm{IU} / 1$ $(p<0.01$, Fisher's exact test). The mean aspartate transaminase activity in surviving patients who had been ill in the first and second trimesters of illness was $474 \mathrm{IU} / 1$, which was not significantly different from that in survivors who had been ill in the third trimester (median 343) or from that in the non-pregnant patients (431 IU/1). Among women whose aspartate transaminase activity on admission was $\geqslant 150 \mathrm{IU} / 1$ the case fatality rate was $14 \%$ in the first and second trimesters compared with $48 \%$ in the third trimester $(p=0.04$, Fisher's exact test).

The seven patients who died in the third trimester of pregnancy had a mean virus concentration of $10^{3.6}$ median tissue culture infective dose $/ \mathrm{ml}$ serum compared with $10^{2 \cdot 33}$ in the patients who survived $(\mathrm{p}=$ 0.035 , Wilcoxon's signed rank test). The mean virus concentration in the pregnant patients however, was, higher than that in the non-pregnant patients $\left(10^{3 \cdot 13}\right.$ median tissue culture infective dose/ $\mathrm{ml}$ compared with $10^{2 \cdot 25}(\mathrm{p}=0 \cdot 048$, Wilcoxon $)$ ). Liver tissue from one aborted fetus had a titre of $10^{6 \cdot 0}$ median tissue culture infective dose/g.

The clinical features of the patients were related to the period of gestation. Five of the 28 women admitted in the first two trimesters presented with threatened abortion, two with complete abortion, nine with incomplete abortion, two with septic abortion, and 10 with a normal pregnancy. Eight of the 40 women admitted in the third trimester presented with an intrauterine death (two had symptoms suggesting a detached placenta), six had puerperal infection after delivery at home during the previous week, three presented with premature labour, three were in labour at term, and one had an obstructed labour. Nineteen presented without obstetric complications but were acutely ill with a wide range of signs and symptoms, chiefly fever, pharyngitis, cough, retrosternal pain, conjunctivitis, and proteinuria. ${ }^{8}$ Nine of the 28 patients in the first two trimesters received at least one dose of ribavirin and one died. Four of the 40 in the third trimester received ribavirin and one died.

Twenty of 28 women aborted in their first or second trimester (table II); they had heavy vaginal bleeding, a high temperature $\left(>38.5^{\circ} \mathrm{C}\right)$, hypotension, and a foul purulent vaginal discharge. Six women in the first and second trimesters were discharged with a normal pregnancy. Eleven women required evacuation of retained products of conception and rapidly recovered, becoming afebrile within 24 hours. Labour was induced in patients near term, and two women 
TABLE II-Outcome of pregnancies in women with Lassa fever. Values are numbers (percentages)

\begin{tabular}{lcc}
\hline & $\begin{array}{c}\text { First and second } \\
\text { trimesters }(\mathrm{n}=28)\end{array}$ & $\begin{array}{c}\text { Third } \\
\text { trimester }(\mathrm{n}=\mathbf{4 0})\end{array}$ \\
\hline Abortions & $20(71)$ & \\
Maternal deaths with dead & $2(7)$ & $8(20)$ \\
$\quad$ fetus in utero & $1(4)$ & $9(23)$ \\
Stillbirths & $2(7)$ & $15^{\star}(8)$ \\
Normal births & 25 & 31 \\
\hline Known outcome & $23(92)$ & $24^{\star}(75)$ \\
Overall fetal loss & 0 & 7 \\
Neonatal deaths & &
\end{tabular}

*One set of twins.

required emergency caesarean section for obstructed labour.

Patients often improved rapidly after delivery, spontaneous abortion, or evacuation of retained products of conception. Of the 14 mothers who died, 10 died with a dead fetus in utero, whereas 35 of the 51 who survived aborted or delivered ( $p=0.0016$ Fisher's exact test). The odds ratio for death from Lassa fever with pregnancy intact was 5.47 (95\% confidence interval $1 \cdot 35$ to $22 \cdot 16$ ). Nineteen pregnancies continued intact, and three eventually ended in stillbirths. Three live infants were delivered prematurely in the third trimester to mothers acutely infected with Lassa fever, and none of the babies survived. Of the patients who survived Lassa infection in the first and second trimesters with their pregnancies intact, three delivered prematurely, and only one baby survived.

We were able to follow the outcome of 56 pregnancies, from which only 14 live infants (one set of twins) resulted, a loss of $75 \%$. As there were seven neonatal deaths only seven pregnancies were successful and the overall loss was $87 \%$.

The disease was not transmitted to hospital staff during the caesarean sections or at any time to other patients or staff on the wards in the hospital. One midwife, who was not immune, contracted Lassa fever while she was inducing labour. She was wearing gloves but no mask or gown, and blood and mucus splashed her face when a balloon catheter she was inserting ruptured in the cervical canal. She recovered uneventfully.

\section{Discussion}

This study provides prospective data on the outcome of Lassa fever in pregnant women compared with women of the same age range and population who were admitted during the same period to the same hospital. We found that Lassa fever carries a high risk to the fetus throughout pregnancy and to the mother, especially in the third trimester. The importance of this infection in pregnancy is emphasised by the finding that in our hospital Lassa fever was the most common single cause of maternal death (25\%), a reflection of the frequency of the infection in this hospital: up to $15 \%$ of all adults admitted have Lassa fever and $30 \%$ of adults die from it. ${ }^{3}$

Although our study clearly shows that Lassa fever carries a high risk of maternal death in the third trimester, the overall case fatality rate in pregnancy was little different from the rate among non-pregnant women admitted to hospital with Lassa fever, ${ }^{8}$ in contrast with previous reports of case fatality rates of $50-70 \% .{ }^{6710}$ Those studies did not stipulate the trimester and took into account only the most severe cases. The patients may have received less aggressive obstetric management of the complications of pregnancy. With such management the maternal death rate in the third trimester in our study might have been even higher, as patients seemed to improve rapidly after delivery or abortion. Our experience has shown the benefit of active obstetric management (including caesarean section if indicated) in the interest of the mother, which remains our first priority in view of the appalling fetal loss due to this infection.

Though there is uncertainty about the function of the immune system in pregnancy, ${ }^{11}{ }^{12}$ there is nevertheless extensive documentation from studies on both humans and mice that in pregnancy, and especially late pregnancy, viruses are more likely to spread rapidly and to reach high titres in tissues and produce more severe disease. ${ }^{910}$ The high correlation in Lassa fever between the severity of viraemia and outcome $e^{5}$ was confirmed in our study. Pregnant patients had significantly higher virus concentrations than non-pregnant patients, and the extremely high titre of virus found previously in placental tissue suggests that the placenta may be a preferred site for viral replication. These observations taken together suggest that the higher mortality from Lassa fever in the third trimester may be related to severe viraemia resulting from relative immunosuppression during that stage of pregnancy. Similar observations of increased case fatality rates in pregnancy have been reported for other infections-(hepatitis, amoebic colitis, typhoid fever, smallpox, coccidioidomycosis, falciparum malaria, poliomyelitis, influenza, tuberculosis, and pneumococcal pneumonia) and increased severity of disease in the third trimester has been reported for influenza, cholera, measles, varicella, diphtheria, scarlet fever, gonorrhoea, giardiasis, and babesiosis.

Lassa fever is devastating to the fetus and the neonate: in our study $87 \%$ of fetuses and neonates were lost. Finding the virus in fetal tissues confirms that the fetus has been infected, though no signs of fetal maldevelopment have been recorded. ${ }^{+}$We previously observed several infections and deaths in neonates after their mothers had been infected late in pregnancy or in the neonatal period (P A Webb and J B McCormick, unpublished data). Lassa virus is known to be present in the breast milk of infected mothers. Neonates are therefore at risk of congenital, intrapartum, and puerperal infection with Lassa virus. In view of the small numbers of surviving fetuses the long term consequences of congenital infections and the possibility of minor abnormalities have not yet been studied and would be difficult to assess.

In areas where it is endemic, Lassa fever should immediately be suspected in febrile pregnant patients, who should be isolated as far as possible; and basic barrier nursing by experienced staff should be strictly adhered to in all circumstances. ${ }^{13}$ Ribavirin, which is an effective treatment in non-pregnant patients, should be administered only after delivery, pending the results of current studies of the safety of its use in pregnant patients. Obstetric complications are frequent and often include interuterine death; they should be actively managed by evacuation of retained products of conception, induction of labour, or caesarean section for obstructed labour.

The copyright for this article is held by the Centers for Disease Control, Atlanta.

We thank Luanne Elliott and Anne Porter for isolating the virus in Atlanta, Georgia. This work was supported in part by Interagency Purchase Authority No 83-8330 from the United States Army Medical Research and Development Command.

1 Brabin BJ. Epidemiology of infection in pregnancy. Rev Infect Dis 1985; 579-603.

Weinberg ED. Pregnancy-associated depression of cell-mediated immunity. Rev Infect Dis 1984;6:814-31.

3 McCormick JF, Webb PA, Krebs JW, Johnson KM, Smith ES. Lassa fever: prospective study of its epidemiology and ecology. I Infect Dis 1987;155: 437-44.

4 Walker DH, McCormick JB, Johnson KM, et al. Pathologic and virologic study of fatal Lassa fever in man. Am f Pathol 1982;107:349-56.

5 Johnson KM, McCormick JB, Webb PA, Smith E, Elliott LH, King IJ. Lassa 
fever: clinical virology in hospitalized patients. $J$ Infect Dis 1987;155: 456-64.

6 Fraser DW, Campbell CC, Monath TP, Golf PA, Gregg MB. Lassa fever in the eastern province of Sierra Leone, 1970-1972. I. Epidemiologic studies. Am J Trop Med Hyg 1974;23:1131-9.

7 Keane E, Gilles HM. Lassa fever in Panguma Hospital, Sierra Leone, 1973-6. BrMed J 1977; ;:1399-402.

8 McCormick JB, King IJ, Webb PA, et al. Lassa fever: a case-control study of the clinical diagnosis and course. I Infect Dis 1987;155:445-55.

9 McCormick JB, King IJ, Webb PA, et al. Lassa fever: effective therapy with ribavirin. N Engl J Med 1986;314:20-6.
10 Monath TP, Mertens PE, Patten R. A hospital epidemic of Lassa fever in Zorzor, Liberia, March-April, 1972. Am J Trop Med Hyg 1973;22:773-9.

11 Smart YC, Cox J, Roberts TK, Brinsmead MW, Burton RC. Differential effect of cigarette smoking on recirculating T-lymphocyte subsets in pregnant women. I Immunol 1986;137:1-3.

12 Lederman MM. Cell-mediated immunity and pregnancy. Chest 1984;86:6-9S. 3 Helmick CG, Scribner CL, Webb PA, Krebs JW. No evidence for increased risk of Lassa fever infection in hospital staff. Lancet 1986;ii:1202-4.

(Accepted II May 1988)

\title{
High prevalence of diabetes in an urban population in south India
}

\author{
A Ramachandran, M V Jali, V Mohan, C Snehalatha, M Viswanathan
}

\begin{abstract}
An urban population in a township in south India was screened for diabetes with an oral glucose tolerance test, every fifth person aged 20 and over registered at the local iron ore company's hospital being screened. Of 678 people (346 men and 332 women) who were tested, 34 ( $5 \%$; 20 men and 14 women) had diabetes and 14 (2\%; 8 men and 7 women) had impaired glucose tolerance. Thirteen subjects were already known to be diabetic. Diabetes was present in $21 \%(37 / 179)$ of people aged over 40 . The peak prevalence $(41 \% ; 7 / 17)$ was in the group aged 55-64. A family history of diabetes was present in 16 of the 34 subjects with diabetes and nine of the 15 with impaired glucose tolerance. Diabetes was signifcantly related to obesity in women but not in men $(57 \%(8 / 14) v 5 \%(1 / 20))$. The plasma glucose concentration two hours after glucose loading was correlated to body mass index, age, and income in both sexes. The prevalence of diabetes was significantly higher in subjects whose income was above the mean.
\end{abstract}

When the overall prevalence of diabetes was adjusted to the age distribution of the Indians living in Southall, London, and in Fiji it increased to $10 \%$ and $9 \%$, respectively. The prevalence of diabetes is high among urban Indians and is comparable with the high prevalence seen in migrant Indian populations.

\section{Introduction}

The prevalence of diabetes varies in different populations. A high prevalence has been reported in migrant Indians in South Africa, Fiji, Trinidad, Singapore, and Southall (London). ${ }^{1.5}$ The prevalence in Indians in India was believed to be low, ${ }^{6}$ but a recent survey in Darya Ganj (New Delhi) showed that the prevalence of known diabetes was not different from that seen in Indians in Southall. ${ }^{57}$ The surveys were based on questionnaires, not on results of tests; hence they probably underestimated the actual prevalence of diabetes. We used glucose tolerance tests to determine the prevalence of diabetes in a population in south India.

$\begin{array}{ll}\text { department of } & \text { the previL, head, } \\ \text { India. }\end{array}$

biochemistry

$\mathrm{M}$ Viswanathan, $\mathrm{MD}$, director

\section{Kudremukh Iron Ore Company Hospital, Kudremukh, India MV Jali, MD, assistant medical officer}

Correspondence to: $\operatorname{Dr} A$ Ramachandran, Diabetes Research Centre, Royapuram, Madras 600013 , India.

\section{Patients and methods}

The survey population came from a township in Kudremukh, Chicmagalur district Karnataka, south India. The population of the township includes several hundred executives and skilled and unskilled workers employed by the Kudremukh Iron Ore Company. They and their families are given free medical care in the hospital attached to the company. The staple food of the people is rice. We selected this area for study because population based data could be obtained from the hospital register and the population was relatively stable.

Of the 4619 people registered at the hospital, 3314 were aged 20 and above; they were defined as the target population. A letter requesting participation in the study was written to every fifth person (selected from the registration numbers on the computer list). The overall response was good because of the well organised health scheme for the community and the close rapport between physicians and the families. The defaulters (less than $1 \%$ after three requests) were replaced by the person having the next number on the computer list. The sample was representative of the overall population.

Subjects came to the hospital at 8 am after an overnight fast, and a fasting sample of venous blood was taken for estimation of plasma glucose and serum cholesterol concentrations. Then $75 \mathrm{~g}$ glucose was given orally in $200 \mathrm{ml}$ water, and blood samples were collected after one and two hours. (This glucose tolerance test was not performed if the subject was known to be diabetic and receiving treatment.) During the time between sampling, height, weight, the family history of diabetes, and family income were ascertained.

Glucose tolerance was classified according to the criteria in a report of the World Health Organisation's study group. ${ }^{8}$ Diabetes was diagnosed if the concentration of glucose in fasting venous plasma was $\geqslant 7.8 \mathrm{mmol} / \mathrm{l}$ or if the concentration of glucose in venous plasma two hours after the glucose loading was $\geqslant 11.1 \mathrm{mmol} / \mathrm{l}$, or both. Impaired glucose tolerance was diagnosed if the plasma glucose concentration two hours after the glucose loading was $7 \cdot 8$ to $11 \cdot 1 \mathrm{mmol} / \mathrm{l}$.

The body mass index $\left(\mathrm{kg} / \mathrm{m}^{2}\right)$ of each subject was calculated. Obesity was defined as a body mass index $>25 \mathrm{~kg} / \mathrm{m}^{2}$ in women and $>27 \mathrm{~kg} / \mathrm{m}^{2}$ in men. Family histories of diabetes were ascertained by questionnaire. They were taken as positive only if there was a history of drug treatment for diabetes. Family income was grouped as $<500$, 501-1000, 1001-1500, 1501-2500, and $>2500$ rupees a month.

The plasma glucose concentration was estimated by the orthotoluidine method' and serum cholesterol concentration by the method of Wybenga et al. ${ }^{10}$ Samples were sent to the Diabetes Research Centre, Madras, three times during the study for counterchecking of the plasma glucose and cholesterol concentrations; the coefficient of variation between the two laboratories was 4-8\%.

The $\chi^{2}$ test and Fisher's test were used for univariate analysis. The prevalence adjusted for the age distributions seen in other studies was calculated by the direct standardisation method. " Analyses of variance were used to determine the effect of sex, age, body mass index, and income and the interaction of these factors on the plasma glucose concentrations after 